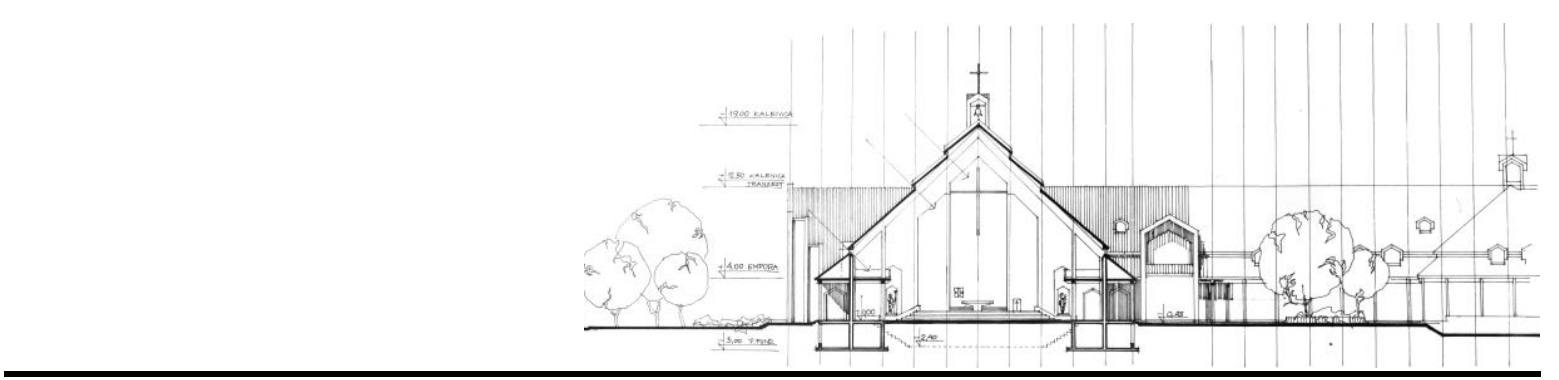

DOI: 10.21005/pif.2021.48.B-03

\title{
SPANNING TRADITION AND MODERNITY - SOME THOUGTS PROMPTED BY THE CHURCH BUILDINGS COMPLEX LOCATED IN KRAKÓW - NOWA HUTA
}

\author{
MIĘDZY TRADYCJĄ A NOWOCZESNOŚCIĄ - NA PRZYKŁADZIE \\ ZESPOKU SAKRALNEGO W KRAKOWIE - NOWEJ HUCIE
}

\section{Jan Kurek}

Dr hab. inż. arch.

Author's Orcid number: 0000-0002-0853-5312

Krakowska Akademia im. A.F. Modrzewskiego

Wydział Architektury i Sztuk Pięknych

\begin{abstract}
Sacred buildings in Poland in the 20th century are characterized by a great variety of forms - although the sacred world is by its nature conservative. Different conditions should be taken into account when designing a church. In the sphere of sacred art and architecture one should rationally draw from the treasury of the new and the old. After World War II over 3,500 new churches were built in Poland, including the church in Nowa Huta in Krakow. This realization is an attempt to reconcile traditional forms with modernity and with the recommendations of the Second Vatican Council.

Key words: sacred architecture, Kraków - Nowa Huta, modernity, tradition.

\section{STRESZCZENIE}

Budownictwo sakralne w Polsce $w$ XX wieku cechuje duża różnorodność form - choć świat sacrum jest ze swej natury zachowawczy. Projektując kościół należy uwzględniać różne uwarunkowania. W sferze sztuki i architektury sakralnej należy racjonalnie czerpać ze skarbca nowego i starego. Po II wojnie światowej powstało w Polsce ponad 3,5 tys. nowych kościołów - w tej liczbie także kościół w Krakowie Nowej Hucie. Realizacja ta jest próbą godzenia form tradycyjnych z nowoczesnością oraz z zaleceniami II Soboru Watykańskiego.
\end{abstract}

Słowa kluczowe: architektura sakralna, Kraków - Nowa Huta, nowoczesność, tradycja. 
As years go by, our neighbourhoods bear witness to the new churches and chapels springing up all around. Some do not warrant our appreciation at all. Now and again, though, we get stunned by the ones exuding an appeal of novelty. We are happy to see them appear in the vicinity, much like the newly designed housing estates which stand out so dramatically from the greyish blocks of flats, a dreary legacy of the bygone communist era in Poland. (Nadrowski 2000, p.13)

Stanisław Rodziński

\section{INTRODUCTION}

Changing trends, styles, and aesthetic forms prevalent in the church architecture indoubtedly offer testimony to their own time. Churches used to look different when they first appeared, they boasted an altogether different look when the first grand medieval cathedrals started to be erected, and they do look dramatically different in modern times, in early $21^{\text {st }}$ century. Even though the domain of sacrum is conservative by its very nature, faithful to specific rites of liturgy and time-honoured ecclesiastical tradition, church architecture also reflects the state of public awareness in respective societies, bearing witness to successive socio-cultural transformations and new trends in common aesthetic appreciation.

The last quarter of the 20th century was reflected in the hands-on implementation of the modifications introduced into the catholic liturgy by the Second Vatican Council (Vaticanum Secundum), which also manifested themselves through the appearance of the newly designed churches.

Father H. Nadrowski noted: We have been in close touch with the arts and the architecture, also of the sacred type, since we were kids. Through various forms of creativity we introduce the art into our everyday lives and festive celebrations. (...) The Church has always been and still is imbued with special symbolism (...) it is a living testimony to human mentality and spirituality, both in terms of individual endeavours and those of entire generations. (Nadrowski 2000, p.15) In father Nadrowski's opinion, it is essential necessary that pastors and vicars, as well as the architects and designers, respect all attendant theological and liturgical ramifications. Whenever those criteria are disregarded, or merely given cursory acknowledgement, the actual outcomes of their professional endeavours tend to fall drastically short of the expectations held by respective congregations. (Nadrowski 2000, p.16)

When setting out to design and build a church, a diversity of constraints must be taken into account, ranging from geographical, geophysical, climatic, structural, material, right up to prevalent regional styles, and even the actual mind-set of the local residents. Taking on board all specific characteristics of a particular environment (including the local communities), should generally prove helpful in bringing a congregation together, helping it get closer to God. Individual participation and collaboration of all those involved in building a church must always be justly acknowledged accordingly.

Indubitably, all endeavours undertaken by the Church over the period spanning two millennia, also in the domain of sacred art and architecture, prove overall need to draw prudently from the treasure trove of the old and the new alike. ${ }^{1}$ Otherwise, the domain of church construction shall be liable to get bogged down in stagnation. The sacrum should never be construed in terms of being a spiritual extra, some sort of an appendix, on the contrary, it should be regarded as its most essential frame of reference.

\footnotetext{
${ }^{1}$ Just as the Gospel's gracious host did in Jesus's parable (Luke, 14, 15-24)
} 
This said, it still remains an open question as to what extent has the spirit of the Second Vatican Council and its resultant resolutions got through to the executive bodies tasked with granting their official seal of approval for the aesthetic appeal of the presently designed churches.

\section{BETWEEN HISTORICISM AND MODERNISM}

In the view of architectural theoreticians (J. Zachwatowicz, T. Barucki), the inter-war period in Poland brought about only two inspiring architectural design projects, including the Church of Divine Providence in Warsaw, whereas Jarosław Wojciechowski, Oskar Sosnowski and Antoni Wiwulski, the architects closely involved in designing the sacred architecture in early 20th century, were the only three big individualities well-worth remembering. That period is characterised by bold rejection of historical motifs, and accompanied by ardent quest for brand-new solutions. (Stefański K. 2003)

Earlier on (i.e. at the turn of the 19th and 20th centuries), apart from making clear-cut references to specific historical styles (e.g. T. Talowski), some aesthetic forms had been sought whose characteristics might well be deemed suitably emblematic for the national style. Most regrettably, however, all architects of some prominence were quite happy to go along with the existing artefacts of wooden church architecture being replaced with the brick-and-mortar counterparts.

Hundreds of Neo-Gothic or Romanesque-Gothic churches, built with brick and mortar, sprang up across the Polish lands at that time. Across the lands in the jurisdiction of the Russian Partition, peculiarity of the so called "Vistula-Baltic" neo-Gothic motifs dominated, whereas in the Podkarpackie region (Austro-Hungarian Partition), Jan Sas Zubrzycki promoted the original Romanesque-Gothic "Vistula style". Teodor Talowski also designed dozens of churches throughout the Austro-Hungarian zone (aka Poland's Galicia region), all of them boasting eclectic motifs, liberally augmented with his very own ideas of architectural ornamentation, addressed at some depth in his publication "Projekta kościołów" ("Church Design Projects"), published by the Czas publishers in 1897.
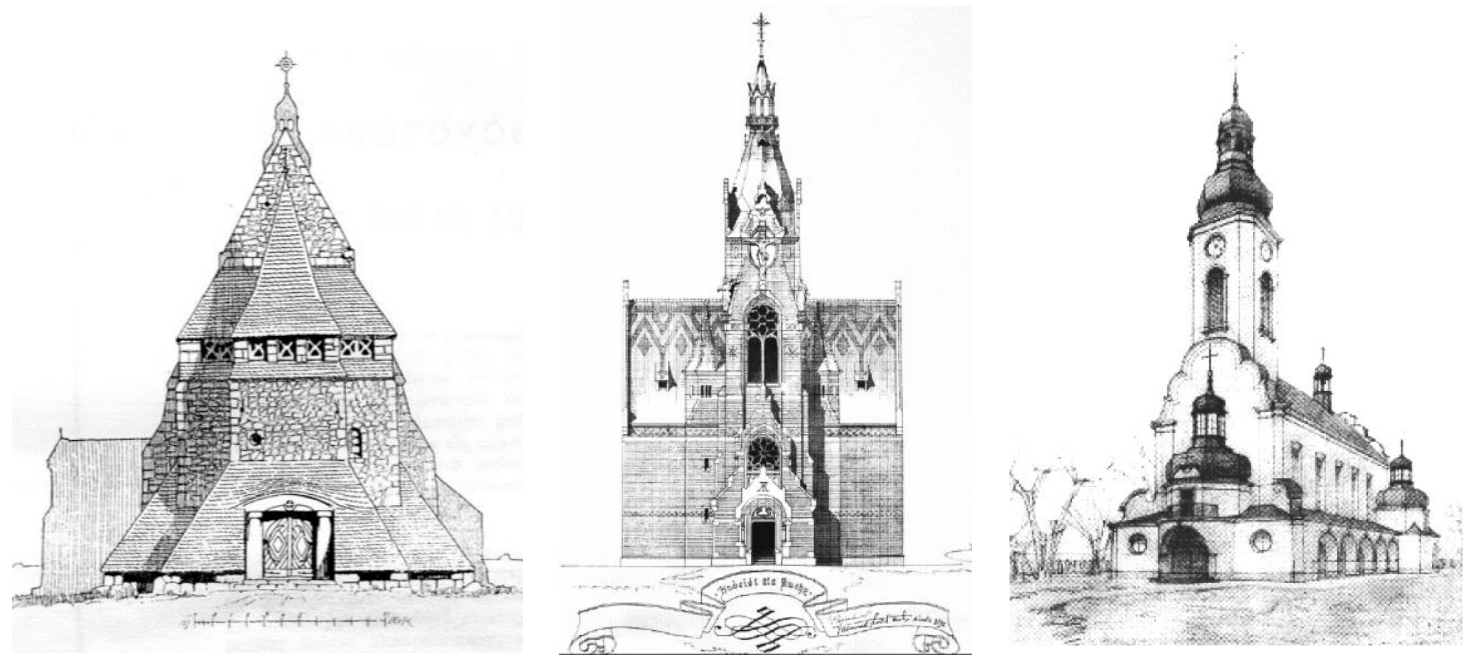

Figs. 1-3. Examples of early 20th c. church designs; from the left: Orłowo - designed by O. Sosnowski 1910, Sucha Beskidzka - designed and implemented by T. Talowski 1895-1907, Brzuchowice - designed by A. Nikodemowicz 1925. Sources: (polskieradio24), (Bystrzak 2017), (Kurek 2012)/

Ryc. 1-3. Przykłady projektów kościołów z początku XX wieku od lewej: Orłowo - proj. O. Sosnowski 1910, Sucha Beskidzka - proj. i relizacja T. Talowski 1895-1907, Brzuchowice - A. Nikodemowicz 1925. Źródła: (polskieradio24), (Bystrzak 2017), (Kurek 2012)/ 
The construction of numerous, visibly over-scaled brick churches throughout Polish villages and small towns was met with bold criticism on the part of the younger generation of architects (Mączeński, Szyszko-Bohusz, Przybylski, Sosnowski, Wojciechowski), who regarded the new churches, especially when juxtaposed against the early modernistic churches of France or Germany, as totally alien to the native landscape. Presently, a hundred years on since their construction, such opinions are have substantially been toned own.
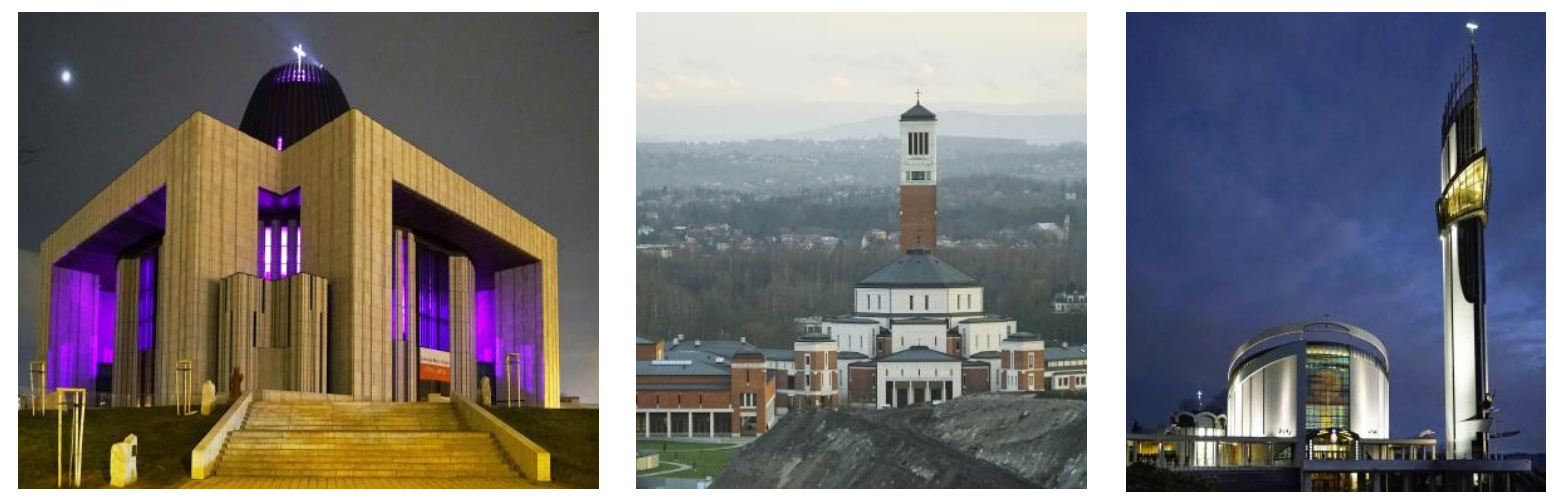

Fig. 4-6. Examples of the churches built in Poland after 1945, from the left: Warsaw - Church of Divine Providence (Szymborski \& Szymborski), Kraków - Sanctuary of St John Paul II (A. Mikulski), Kraków - Sanctuary of the Divine Mercy (W. Cęckiewicz). Source: Photo courtesy of the Author

Ryc. 4-6. Przykłady kościołów zbudowanych w Polsce po 1945 roku, kolejno od lewej: Warszawa - kościół p.w. Opatrzności Bożej (Szymborski \& Szymborski), Kraków - Sanktuarium św. Jana Pawła II (A. Mikulski), Kraków - Sanktuarium Bożego Miłosierdzia (W. Cęckiewicz). Źródło: foto autor
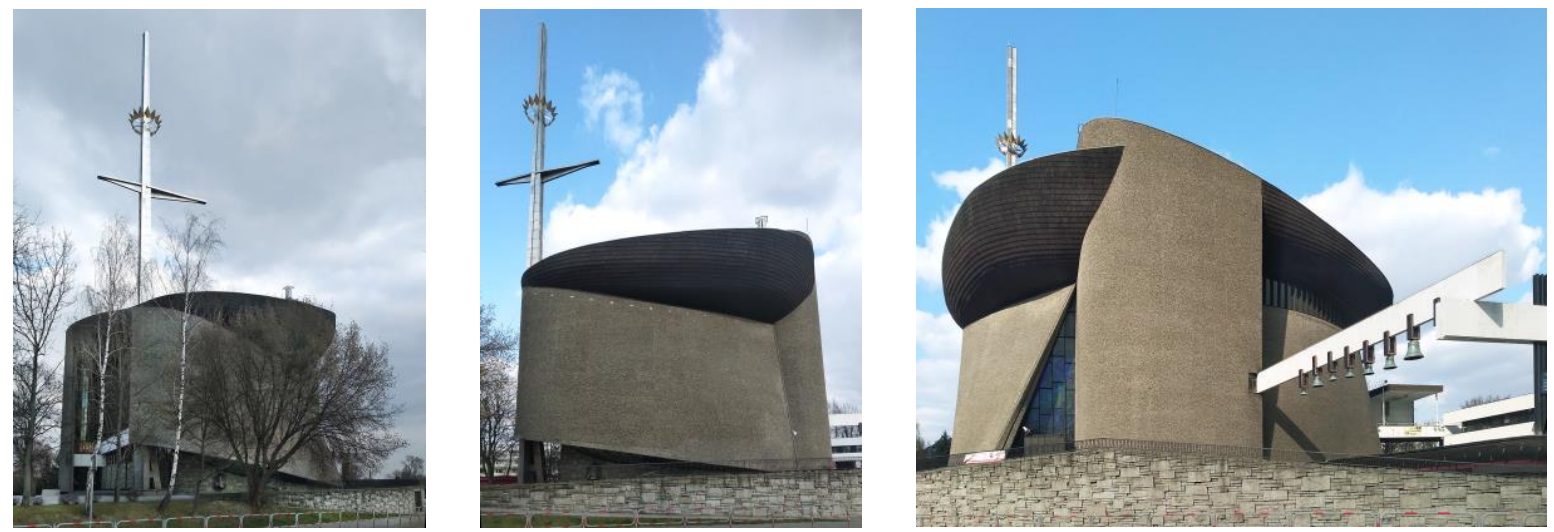

Fig. 7-9. The first church of Our Lady, The Queen of Poland, in Kraków - Nowa Huta (W. Pietrzyk; under construction in 1967-1977). Source: Photo courtesy of the Author

Ryc. 7-9. Pierwszy kościół pw. Matki Bożej Królowej Polski w Krakowie - Nowej Hucie (W. Pietrzyk realizacja 1967-1977). Źródło: foto autor/

\section{THE NEW POST-WAR REALITY}

In 1945, there were 7555 Catholic churches in Poland, whereas in 2016, this number rose to an impressive 10466 churches. Despite generally hostile policy pursued by the Polish post-war communist authorities towards the Church, over 3,500 new churches were built, and this is still remains an ongoing process. ${ }^{2}$ The main driving force behind this church construction boom had been the architects-designers, vicars presiding over the new parishes, and a local congregation, i.e. the ac-

\footnotetext{
${ }^{2}$ In 2016, the Authors of the „Architecture of the 7th Day” Project counted altogether 3781 churches (across Poland).
} 
tual on-site workforce. Churches had mainly been built with the aid of the so called build-it-yourself system, even though all highly specialised construction works were always carried out by the professional outsourced contractors.

The key factor, however, consisted in the dedicated involvement of the congregation itself in moving the building project forward. The more resolute was the actual resistance mounted against the authorities, the more buildings topped with the sign of the cross appeared all around. Every newly built church usually became soon enough yet another hub of independent cultural and political activity. A perfect example of such a church, having risen on the wave of civic resistance against the authorities (1969) was the first church in Krakow's working-class district of Nowa Huta.

The architectural zoning plan, as officially endorsed for this particular district, did not actually provide for the location of a church. When the authorities eventually agreed to the construction of the much celebrated "Noah's Ark" church in Nowa Huta in the 1970s, they also agreed to the construction of more churches, including the one for the parish of St Joseph, covering the area of four housing estates, i.e. os. Kalinowe, os. Strusia, os. Wysokie, and os. Na Lotnisku. At the time, this parish boasted a total population of approx. 26,000 souls.

Paradoxically, the largest number of new churches (1126) had been constructed in Poland when General Jaruzelski was in power. New churches were being opened every three days on average back then. As social, political and economic transformation gradually progressed across the country, this rapid construction pace somewhat slowed down. Back in 1986, however, there were still some 900 new churches under construction at the same time.
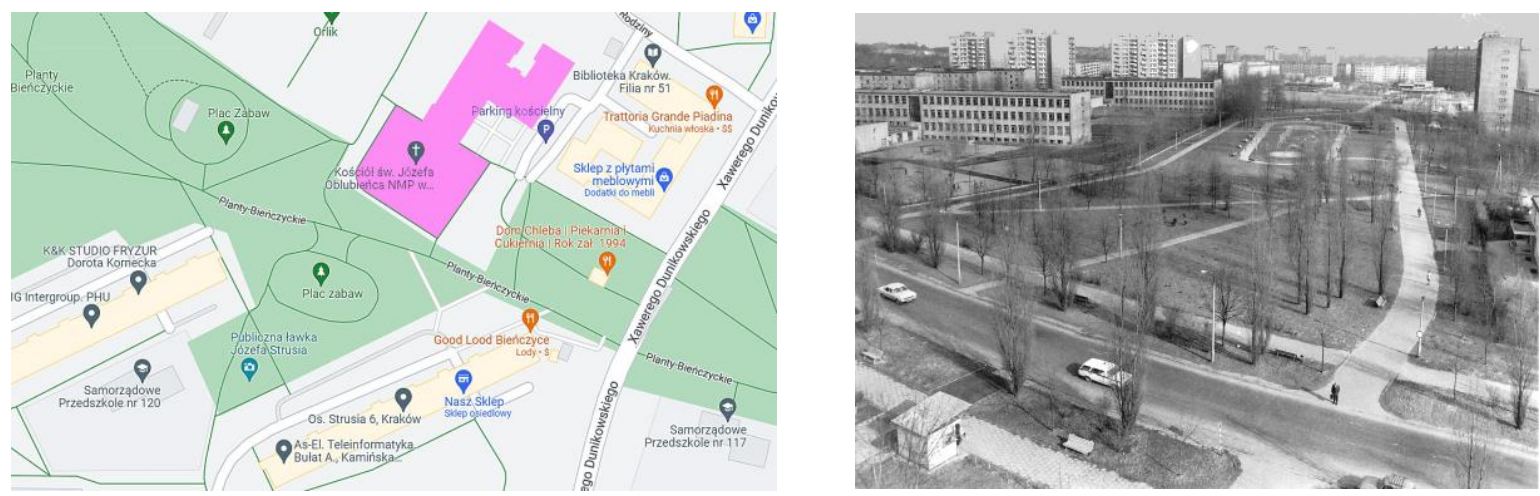

Fig. 10-11. The siting of St. Joseph's parish complex in the midst of the housing estates in Nowa Huta - a photograph also depicts the so-called Planty Bieńczyckie. Source: Author's archive/

Ryc. 10-11. Lokalizacja zespołu sakralnego p.w. św. Józefa w zespole osiedli nowohuckich - fotografia prezentuje wygląd tzw. Plant Bieńczyskich. Żródło: archiwum autora/

\section{ORIGINAL CHURCH BUILDINGS COMPLEX}

The originators of the initial conceptual design for this buildings complex, comprised of a church, a rectory, and the premises accommodating the living quarters for the nuns and the priests, were Zofia and Zenon Luczynski. Following a sudden death of Z. Luczyński, a new team of architects, made up of the widowed wife and myself, was appointed in 1985, with the blessing of father Stanisławem Podziorny, the parish priest. (Kurek J. 1998)

In line with the previously agreed arrangements, the whole project was supposed to be directly reminiscent of an old monastery, of a slightly rustic character, in terms of its spatial layout, i.e. boasting the steep, three-tiered, hipped roofs. We reached the consensus whereby overall design of the complex should in no way challenge the neighbouring, large-scale 10-storey blocks of flats. 
At the same time, out topmost priority consisted in remaining fully compliant with general liturgical guidance and specific recommendations, as passed down by the Second Vatican Council.

At that time, several other churches were already under construction in Nowa Huta, alas this by no means implied that the actual construction of this newly designed church complex would be implemented in a trouble-free manner. To begin with, it was essential to secure the endorsement of the Curial Commission, whose consultant in architectural design at the time was Professor Witold Cęckiewicz. The Commission ordered that two versions of the conceptual design project for the church be presented.

In one of them, the body of the church was of a far more compact character, whereas in the other one, the actual footprint of the church was much closer reminiscent of the Latin cross. Both variants proposed that the church be devoid of a proper spire, with only a simple steeple topped with a cross, located over the point where the main nave and the transept intersected. Ultimately, the second version of the conceptual design, drawing more directly on the traditional church architecture, won the Commission's endorsement.
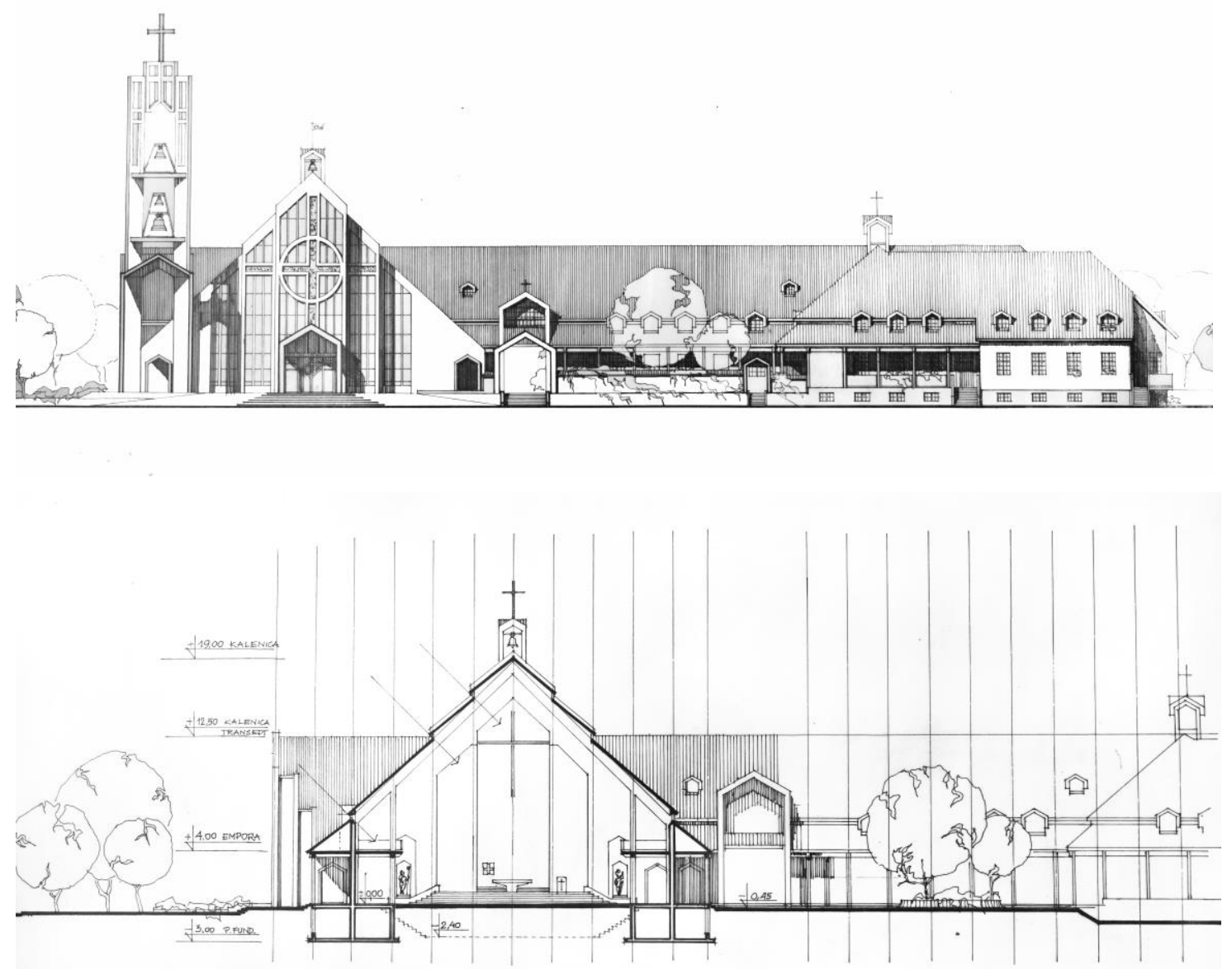

Fig. 12-13. Kraków - Nowa Huta, one of the variants of the newly designed church, boasting a free-standing church tower eastern elevation and a cross-section. Source: Drawing courtesy of the Author

Ryc. 12-13. Kraków - Nowa Huta, jeden z wariantów nowoprojektowanego kościoła z wolnostojącą wieżą - elewacja wschodnia I przekrój poprzeczny. Źródło: Rys. autor 
Another stumbling block to be overcome was the obligation to secure the approval of the Municipal Urban and Architectural Commission, headed by the Chief Architect of the City of Krakow. The Commission's initial feedback did not address the actual architecture of the church's body, merely demanding that the pedestrian traffic be effectively integrated with the Bieńczyckie Planty greenery, located outside the parish grounds. Ultimately, it took over two years to get hold of the Commission's final endorsement. The actual project implementation progressed much faster, and the body of the church was practically completed without the legally required (and endorsed) executive design project.
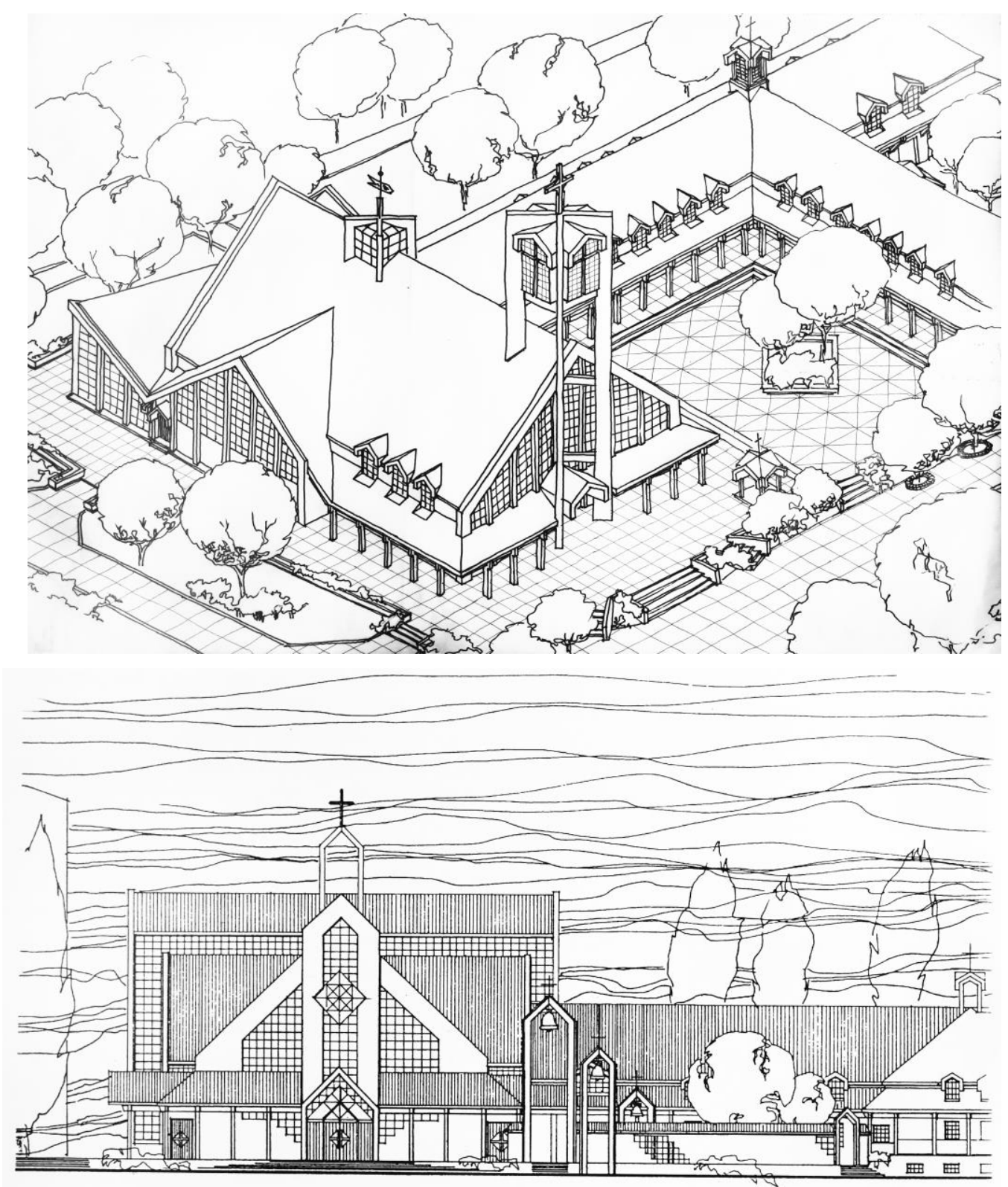

Kościół, elewacja wschodnia - wersja III realizowana

Fig. 14-15. Kraków - Nowa Huta, a projet design variant accommodating a church tower over the main entrance; the east elevation of the project variant, as ultimately selected for implementation. Source: Drawing courtesy of the Author

Ryc. 14-15. Kraków - Nowa Huta, wariant $z$ wieżą nad wejściem oraz elewacja wschodnia wariantu wybranego do realizacji. Żródło: rys. autor 


\section{ADDRESSING THE PRESENT}

As Tadeusz Gawłowski wrote 23 years back in his short essay on overall quality of post-war sacred architecture (Gawłowski J.T. 1998), he was clearly critical of the architectural appeal of the recently built churches, both with regard to the ones built within the period immediately preceding the pontificate of John Paul II, and those erected after 1975.

Despite an impressive number of approx.1500 newly built churches, regretfully enough, none of them boasted suitably high architectural standards, nor indeed exuded the much anticipated aesthetic appeal. In his opinion, this was primarily attributable to insufficient involvement of the individuals whose background was grounded in the artistic and academic domains, whereas professional expertise of the ones supervising the actual construction frequently fell somewhat short of public expectations.

The opinions held by father Janusz Pasierb are often quoted, openly dismissive of any mediocrity and tediously imitative art in design work, as encountered in those design projects. He postulated that the architects should always reach for the skies in their creative endeavours to make the church designs truly outstanding in their aesthetic appeal. (Gawłowski J.T. 1998, p.118)

As father Nadrowski aptly put it: The business of designing and building modern churches is not in a limbo of some sort, or being driven by individual fantasies fused with cheap sentimentalism, or even aspiring to pure aestheticism. [...] Through the actual design premises for a particular church building we are meant to discover and appreciate at the same time the religious mind-set of a particular generation, and the set of values it upholds. This principally also holds true for the architect/designer himself. (Nadrowski H., p.256)
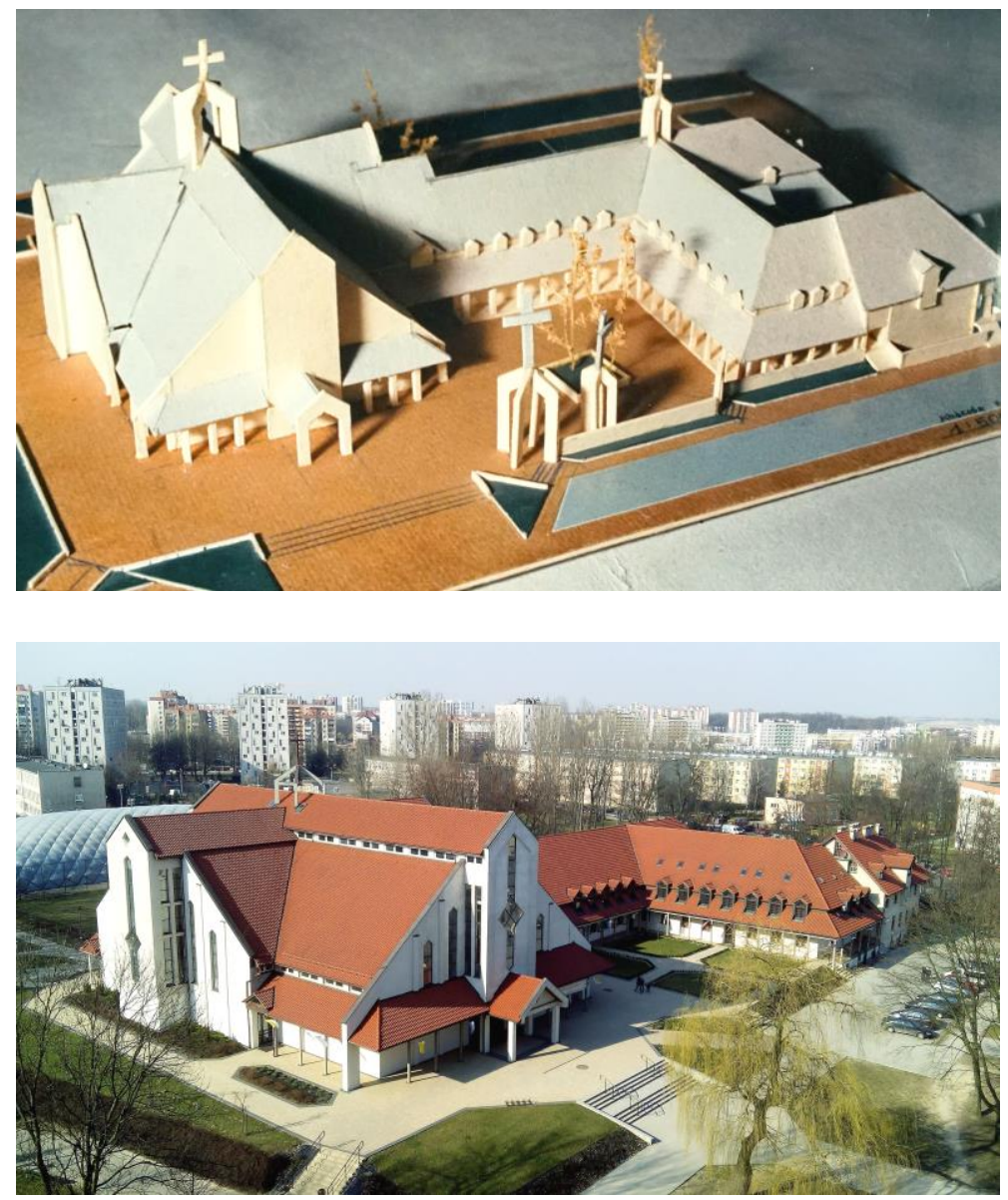

Fig. 16-17. Working model and a view of the entire parish complex in Kraków Nowa Huta, following its completion. Source: Reproduction and photo courtesy of the Author

Ryc. 16-17. Makieta robocza i widok całości zrealizowanego zespołu sakralnego w Krakowie - Nowej Hucie. Źródło: reprod. i fot. Autor 
This view is indubitably supported by the design projects of Stanisław Niemczyk, whose aesthetic sensitivities and deeply personal appreciation of the domain of sacrum in the churches (Kurek J. 2018 p.243) made him an artist very much within his own right. Niemczyk never left anything to chance, and was quite fond of sketching a great deal, firmly believing that things should always be thought through and through, prior to any specific action. So he used to reject any fads, being staunchly opposed to the so-called 'languages of pure forms'. Inspired by his very own heartfelt spirituality, he reached out to the actual roots of Christian creed, proposing truly unique architectural designs, while staunchly upholding all attendant liturgical guidelines and constraints and thus effectively embracing the very spirit of Christian faith. At the same time, he asserted that an architect's duty was always meant to be subservient to the society at large.
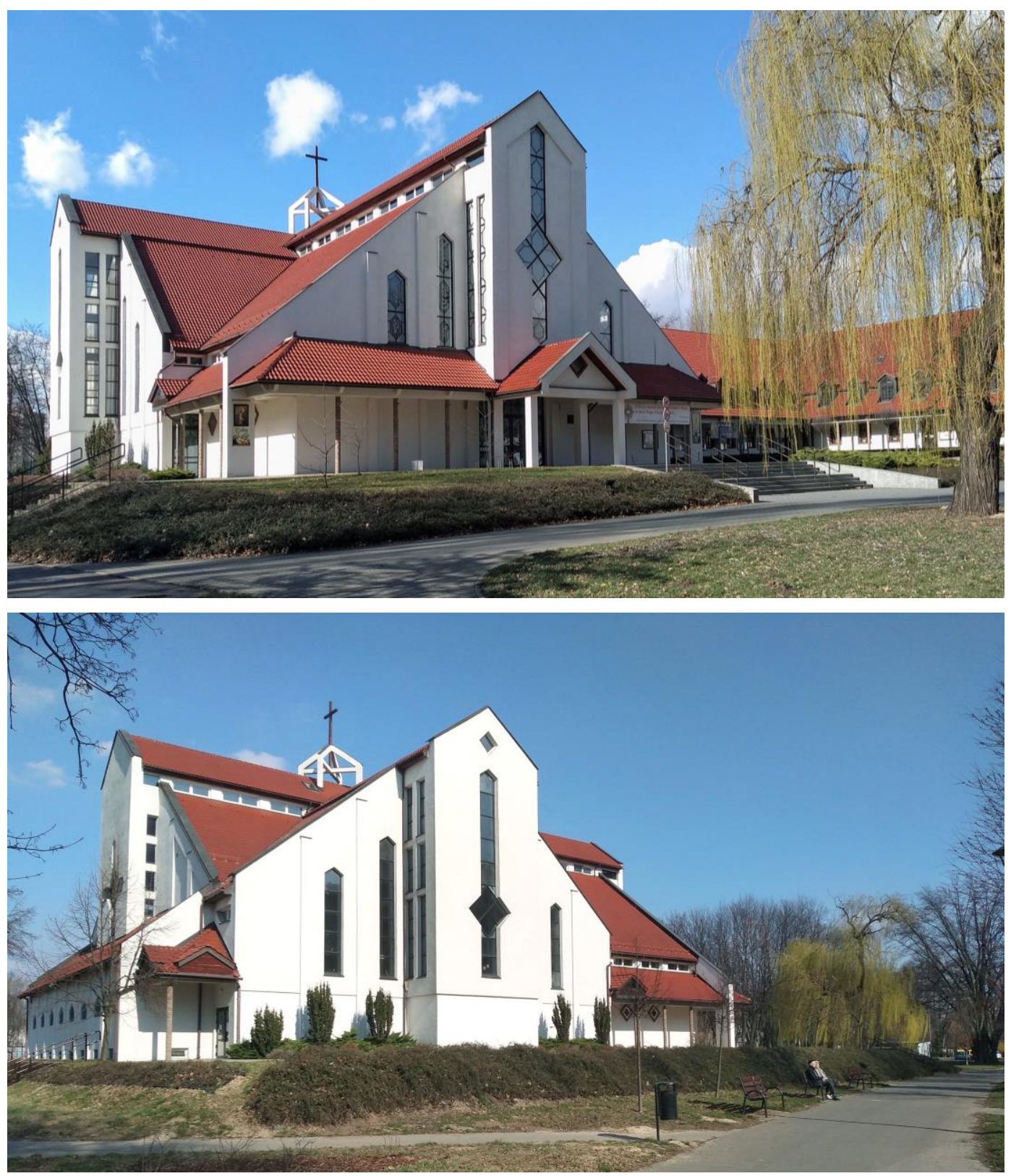

Fig. 18-19. Kraków - Nowa Huta, St. Joseph's Church - present look Source: Photo by the Author

Ryc. 18-19. Kraków - Nowa Huta, kościół pw. św. Józefa - widoki stanu obecnego Źródło: fot. Autor 
Such an attitude and heartfelt humility towards the actual subject matter of the design project does not seem to be overly popular among a vast majority of architects, who are pretty keen on indulging their own narcissist urges, if only to ensure that their achievements would be fondly remembered by posterity.
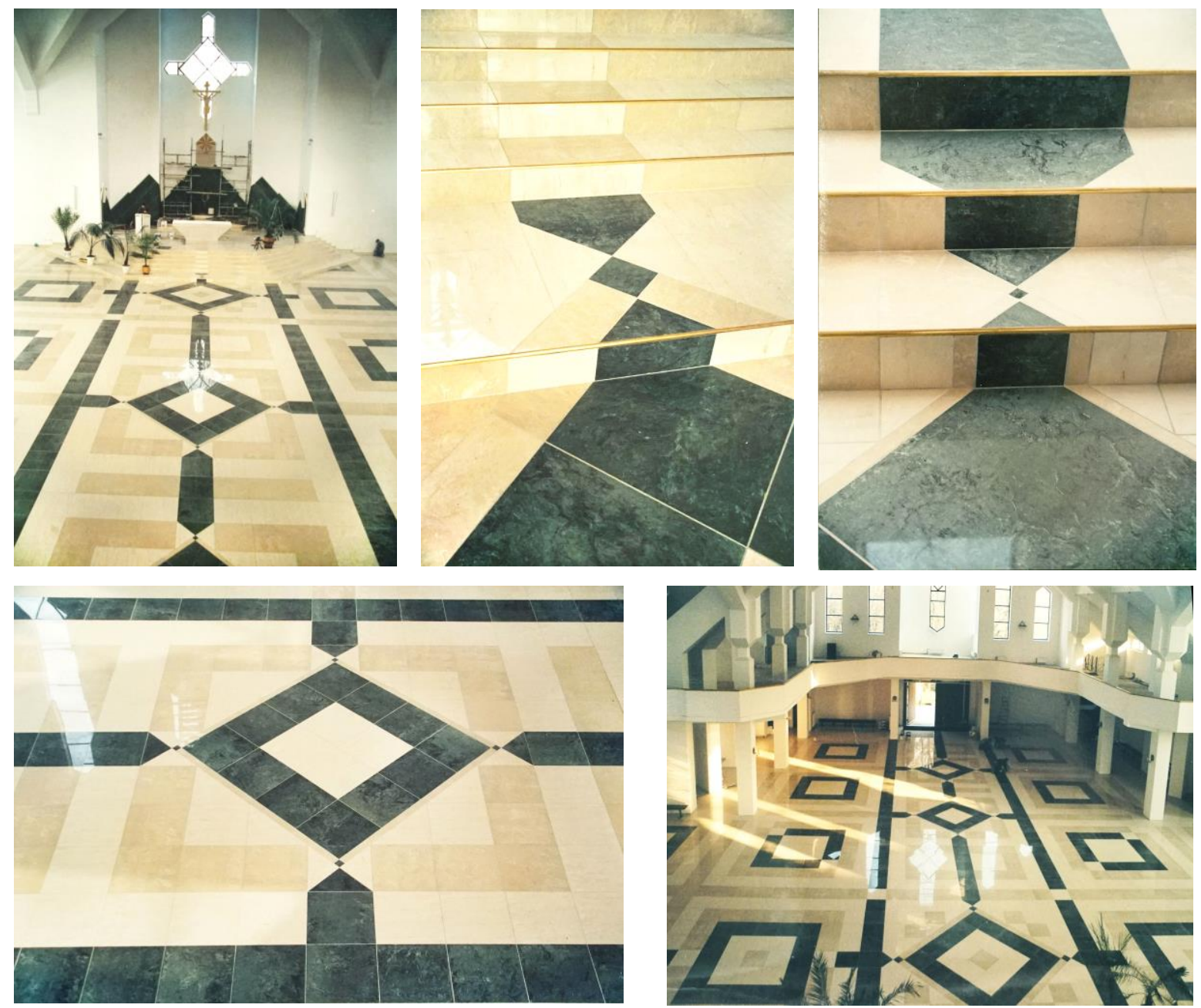

Fig. 20-24. Kraków - Nowa Huta, St. Joseph's Church - the Author's design of the flooring at the ground floor level. Source: Photo courtesy of the Author

Ryc. 20-24. Kraków - Nowa Huta, kościół pw. św. Józefa - autorski project posadzki parteru. Źródło: fot. autor

\section{GAINING SOME INSIGHTS INTO THE VAST CHURCH BUILDING HERITAGE}

With a view to precluding the errors made by numerous predecessors, the design team of the above-referenced Nowa Huta church complex set out to appraise themselves at some depth of the architectural transformations under study, and general condition of the sacred architecture in Poland in the 20th century. The primary objective consisted in gaining some insights (critical assessment) into the prevalent trends manifest at the very design stage of the projects for the new churches, including the logic actually underpinning some specific designs put forward by the architects, in due consideration of the guidelines and recommendations passed down by the Second Vatican Council. At the same time, efforts were made to incorporate in this appraisal, to the widest possible extent both the theoretical considerations and practical conclusions comprised in the ana- 
lytical work of Sister Rosier-Siedlecka (Rosier-Siedlecka 1979), as already released in print at the time. Obviously enough, this in no way detracts from the previous thousand years of experience in erecting the early Christian temples or the grand medieval cathedrals. The intuitive methods of research proved particularly valuable at this stage.
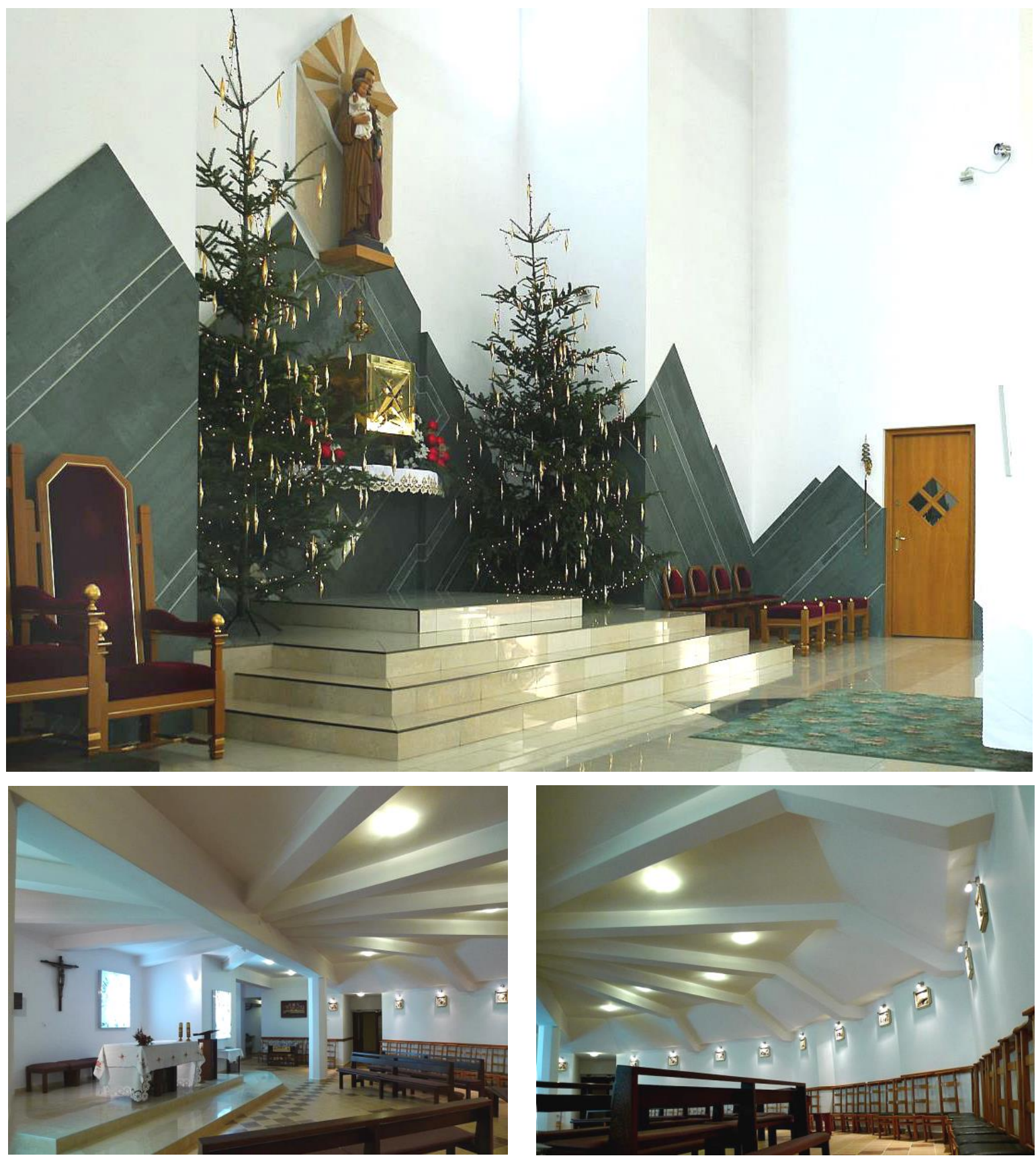

Fig. 25-27. Kraków - Nowa Huta, St. Joseph's Church - the Author's design of the chancel's interior; an interior view of the chapel located under the chancel. Source: Photo courtesy of the Author

Ryc. 25-27. Kraków - Nowa Huta, kościół pw. św. Józefa - autorski projekt wystroju prezbiterium oraz widok wnętrza kaplicy pod prezbiterium. Źródło: fot. autor 
An important component of the project design assessment consisted in an imperative to acknowledge and fully appreciate the effect of the immediate surroundings of the structure under design, as this would allow applying optimal solutions to have this newly designed structure harmoniously integrated with the adjacent housing estate, comprised of medium-sized and large apartment blocks (4-10 storeys high). In modern terms, this was at the time the first attempt at introducing 'sustainable building design' (as it is termed nowadays) on the home turf.

As this church buildings complex has already been around over 20 years in the cityscape of Nowa Huta (i.e. for a generation), this now avails us of a perfect opportunity to have the earlier assessment supplemented with the ongoing observational studies, i.e. a continuous process, combined with a monographic approach, here construed as the evidence -based observation of overall functionality of the project, inclusive of the community feedback regarding the extent of its acceptance for the entire architectural venture.
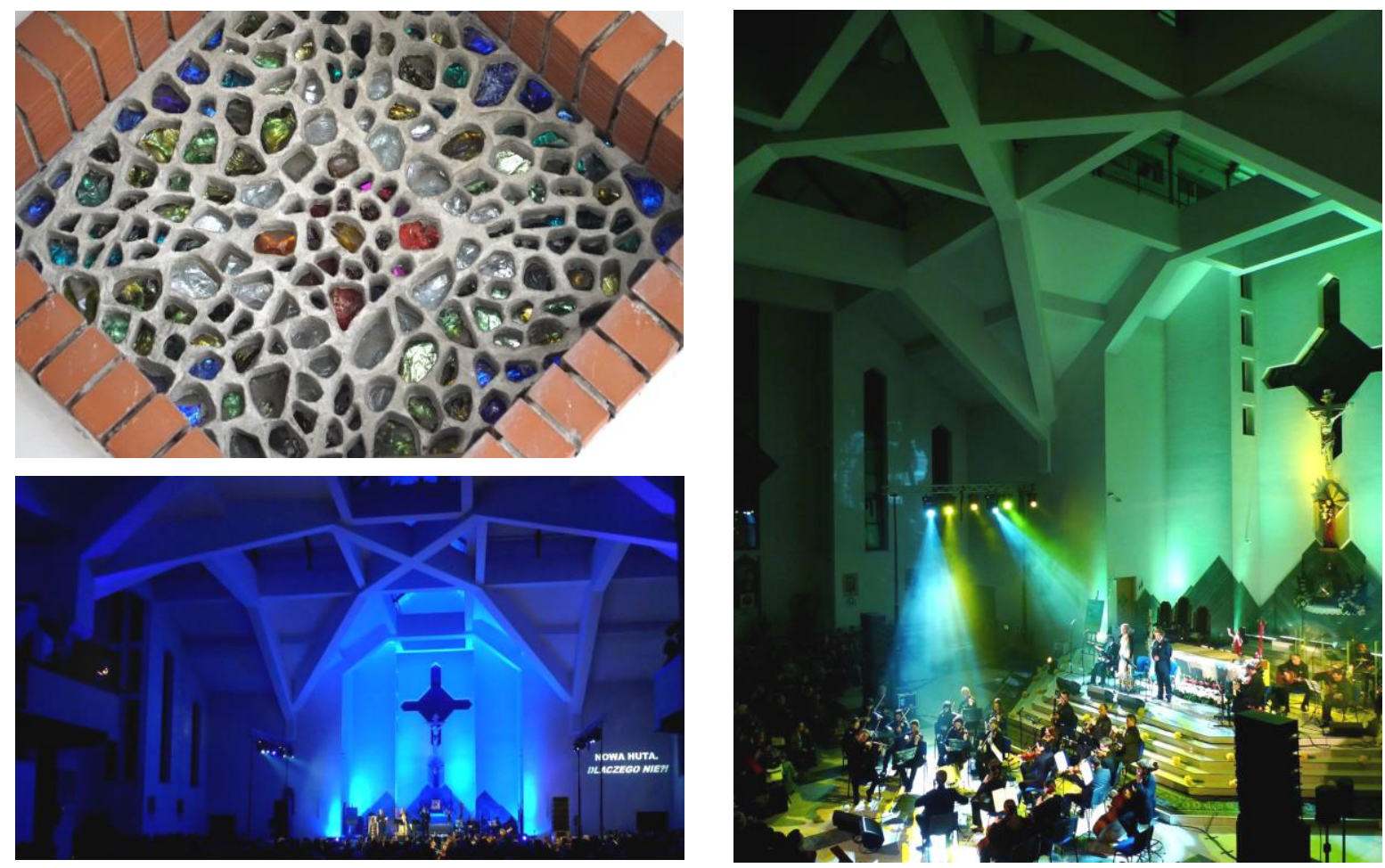

Fig. 28-30. A prototype stained-glass window, crafted by the Author, fitted at the ground floor level; a view of the church interior during the concerts. Source: Photo courtesy of the Author

Ryc. 28-30. Prototypowy witraż szklano-żelbetowy wykonany przez autora dla jednego z okiien parteru oraz widok wnętrza $w$ trakcie koncertów artystycznych. Żródło: fot autor

\section{IN CONCLUSION}

Twenty-five years have lapsed since the complex was commissioned for public use. This gives us a perfect opportunity to evaluate the accuracy of the original design premises and all specific solutions actually adopted at the project implementation stage. Designing the entire complex in the style directly reminiscent of a typical monastic structure, i.e. transplanting medieval design paradigms directly into modernity granted some of the buildings (religious instruction rooms, vicarage, priests' and nuns' living quarters, etc.) the much sought intimacy and tranquillity. The entire complex has also been successfully harmonised with the body of the church itself, as well as and effectively integrated with its immediate surroundings by a system of pedestrian walkways. 
A transitional zone to the neighbouring high residential buildings is provided by the Bieńczyce Planty greenery, successively supplemented by the parish congregation. The slanted lines of the threetiered, hipped roofing stucture of the church and the adjacent buildings of the complex effectively make it all stand out in geometrical terms from the surrounding large-panel residential buildings, dating back to the 1960s. This phenomenon was perceptively acknowledged by one of the panellists ${ }^{3}$ during an in-house debate held at the Municipal Urban and Architectural Commission, who asserted that the church complex looked as it had been sited there long before the housing estates were built...

This brings to mind the concept of constructive conservatism (Kosiński W., 1998) adopted by the late Wojciech Kosiński, who recalled John Paul Il's statement asserting that remaining true to one's roots is always imbued with an inner sense of creativity, readiness to delve deep, remaining open to the new challenges, sensitive to the signs of the times. It also expresses itself in caring for the development of native cultural traditions. Remaining true to one's roots is to be construed as, above all, an individual ability to foster an organic bond between the time-honoured values that have proven themselves time and time again in history, and the challenges posed by the modern world.
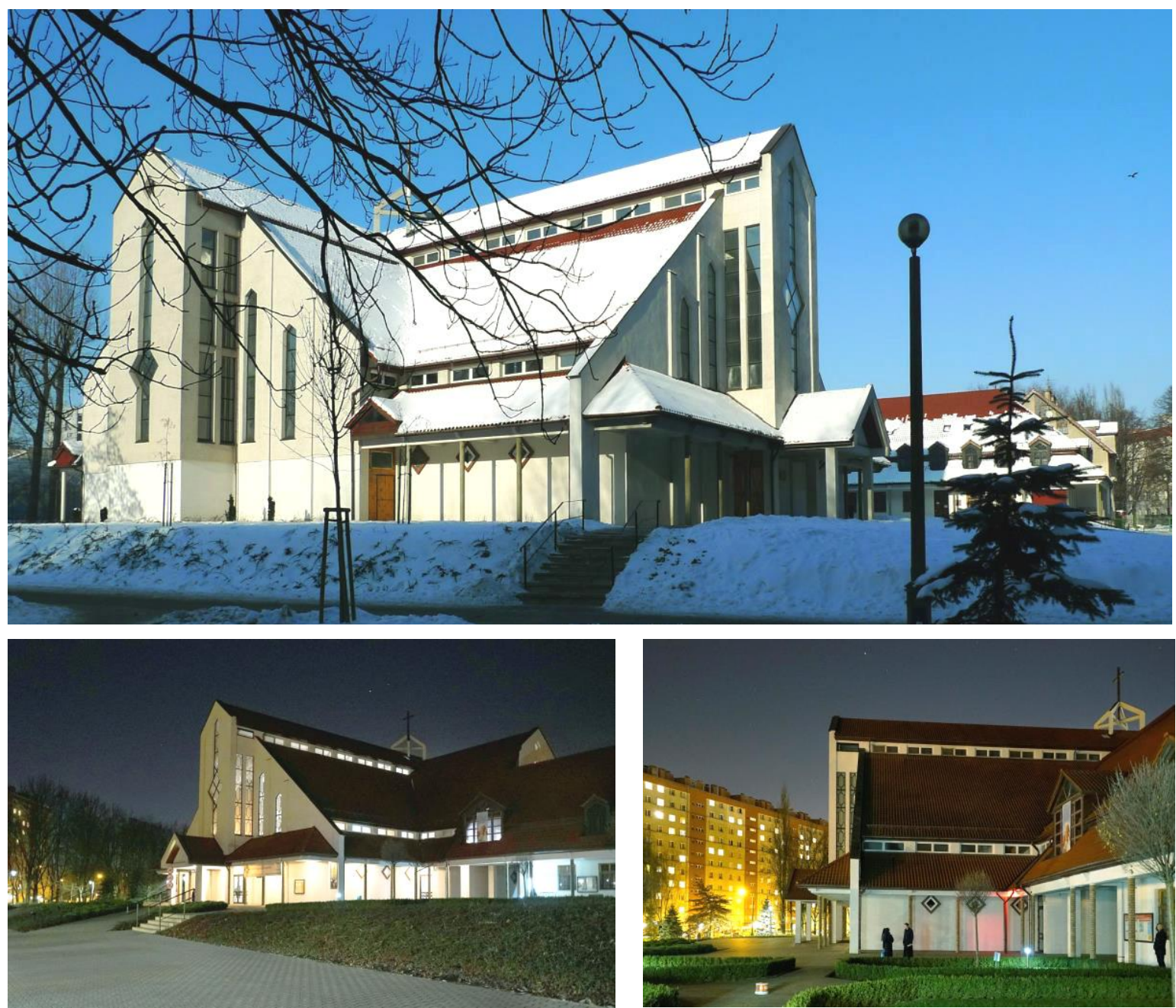

Fig. 31-33. Kraków - Nowa Huta, St. Joseph's Church - present look. Source: Photo courtesy of the Author Ryc. 31-33. Kraków - Nowa Huta, kościół pw. św. Józefa - widoki stanu obecnego. Źródło: fot. autor

${ }^{3}$ Prof. Dariusz Kozłowski. 


\title{
MIĘDZY TRADYCJA A NOWOCZESNOŚCIA - NA PRZYKŁADZIE ZESPOŁU SAKRALNEGO W KRAKOWIE - NOWEJ HUCIE
}

\begin{abstract}
Od szeregu lat krajobraz nasz zaludnia się nowo zbudowanymi kościołami i kaplicami. Nieraz te nowe świątynie po prostu się nam nie podobają, nieraz to, co w nich nowe i zaskakujące zadziwia nas. I cieszymy się z tych nowych i innych trochę kościołów, jak z nowych domów mieszkalnych - tak innych przy szarych peerelowskich blokach. (Nadrowski 2000, p.13)
\end{abstract}

Stanisław Rodziński

\section{WSTĘP}

Zmieniające się tendencje, style i formy, realizowane w budownictwie sakralnym, są niewątpliwie świadectwem swego czasu - inne były kościoły u swego zarania, inne w czasach katedr i inne są w czasach dzisiejszych, na przełomie wieków. Choć świat sacrum ze swej natury jest zachowawczy - wierny liturgii i tradycji - to jednak budynki sakralne są również odzwierciedleniem stanu świadomości społeczeństw odzwierciedlającego kolejne przemiany społeczno-kulturowe oraz zmieniających się gustów artystycznych i stylów artystycznych.

Ostatnie ćwierćwiecze XX wieku to także swoista praktyczna projekcja realizacji zmian wprowadzonych w liturgii przez II Sobór Watykański w formach nowoprojektowanych kościołów. Jak zauważa H. Nadrowski (Nadrowski 2000, p.15) Ze sztuką, z architekturą - także religijną i sakralną zżywamy się od wczesnego dzieciństwa. Poprzez przeróżne formy twórczości wprowadzamy ją w naszą codzienność i odświętność. (...) Kościół był i jest szczególnym znakiem (...) jest też świadectwem mentalności i duchowości, tak poszczególnych jednostek jak i całych pokoleń danego czasu (Nadrowski 2000, p.15). Zdaniem ks. Nadrowskiego konieczne jest respektowanie przez proboszczów-zleceniodawców i przez projektantów, uwarunkowań teologiczno-liturgicznych, a pomijanie tych kryteriów, lub traktowanie zdawkowe, jest zasadniczą przyczyną nieudanej twórczości związanej z budynkiem kościelnym. (Nadrowski 2000, p.16)

Projektując i budując kościół należy uwzględniać różne uwarunkowania - od geograficznych, geofizycznych i atmosferycznych, przez konstrukcyjno-materiałowe po stylistyczno-regionalne i mentalne. Uwzględnienie uwarunkowań konkretnego środowiska (także lokalne społeczności), generalnie rzecz biorąc, powinno pomagać w zbliżeniu do Boga. Nie wolno zaniedbywać współuczestnictwa i współdziałania wszystkich związanych z dziełem budowy kościoła. Niewątpliwie dwa tysiąclecia działalności Kościoła - także w sferze sztuki i architektury sakralnej - pokazują potrzebę racjonalnego czerpania ze skarbca nowego i starego ${ }^{4}$. W przeciwnym razie budownictwu sakralnemu grozi zastój i regres. Sacrum nie powinno być dodatkiem-uzupełnieniem budynku kościoła, lecz powinno stanowić jego istotę. Otwartym pozostaje jednak pytanie na ile duch Soboru Watykańskiego i jego dokumenty, znalazły właściwe zrozumienie w gremiach mających wpływ na uformowanie współczesnych kościołów.

\section{MIĘDZY HISTORYZMEM A MODERNIZMEM}

Zdaniem teoretyków architektury (J. Zachwatowicz, T. Barucki) okres międzywojenny zaowocował w Polsce jedynie dwoma interesującymi projektami konkursowymi - w tym na kościół Opatrzności Bożej w Warszawie, a do indywidualności, zajmujących się architekturą sakralną w pocz. XX wieku, zalicza się Jarosława Wojciechowskiego, Oskara Sosnowskiego i Antoniego Wiwulskiego. Okres ten cechuje odrzucanie motywów historycznych i intensywne poszukiwanie nowych rozwiązań (Stefański K., 2003). Wcześniej jednak (przełom XIX i XX w.), oprócz nawiązywania do stylów historycznych (np. T. Talowski), zaczęto poszukiwać form które można by uznać za właściwe dla

\footnotetext{
${ }^{4}$ Jak to czynił ewangeliczny dobry gospodarz (Łukasz, 14, 15-24)
} 
stylu narodowego. Niestety znani architekci ochoczo akceptowali wymianę istniejącej substancji drewnianej na obiekty sakralne murowane.

$\mathrm{Na}$ ziemiach polskich wyrastały setki świątyń o ceglanych formach neogotyckich lub romańskogotyckich. Na terenie zaboru rosyjskiego dominowały motywy neogotyku „wiślano-bałtyckiego”, na Podkarpacie (Galicja) brylował Jan Sas Zubrzycki propagował autorski romańsko-gotycki „styl nadwiślański”. Także Teodor Talowski realizował dziesiątki kościołów w Galicji o wątkach eklektycznych, dodatkowo wzbogaconych o własne pomysły formalne, upowszechniane w jego publikacji pt. „Projekta kościołów” (wyd. Czas, 1897).

Budowanie w polskich wsiach i miasteczkach wielu przeskalowanych murowanych świątyń z czasem spotkało się z krytyką młodszego pokolenia architektów (Mączeński, Szyszko-Bohusz, Przybylski, Sosnowski, Wojciechowski), uważającego nowe świątynie - na tle wczesnomodernistycznych kościołów Francji czy Niemiec - za obce ciało w rodzimym krajobrazie. Dziś, po ponad stuleciu od ich powstania, świątynie te doczekały się bardziej stonowanych opinii.

\section{POWOJENNA NOWA RZECZYWISTOŚĆ}

W roku 1945 istniało w Polsce 7555 kościołów katolickich, natomiast w 2016 roku kościołów jest już 10466 ... - czyli mimo nieprzychylnej Kościołowi polityki powojennej komunistycznej władzy powstało ponad 3,5 tysiąca nowych świątyń ${ }^{5}$ i proces ten trwa nadal. Głównymi siłami sprawczymi tego boomu budowlanego byli projektanci-architekci, proboszczowie nowych parafii oraz wierni - siła robocza. Kościoły budowano głównie systemem gospodarczym, ale do wykonania bardziej odpowiedzialnych konstrukcji angażowano także specjalistyczne przedsiębiorstwa budowlanomontażowe. Kluczowe jednak było zaangażowanie wiernych - im bardziej rósł opór wobec władz, tym bardziej przybywało budynków wieńczonych znakiem krzyża, a każda nowa świątynia stawała się zwykle kolejnym ośrodkiem niezależnego życia kulturalnego i...politycznego. Przykładem świątyni wyrosłej na fali społecznego oporu wobec władzy (1969) był pierwszy kościół w krakowskiej dzielnicy robotniczej Nowa Huta. W projekcie architektonicznym tej dzielnicy bowiem nie przewidziano lokalizacji kościoła. Po zgodzie władz na budowę słynnej już dzisiaj nowohuckiej „Arki”, w latach 70. Przyszła również kolej na zgody na budowę następnych kościołów - w tym także dla parafii św. Józefa, obejmującej cztery nowohuckie osiedla: Kalinowe, Strusia, Wysokie i Na Lotnisku. Parafia ta skupiała wówczas łącznie ok. 26 tys. mieszkańców.

Paradoksalnie najwięcej nowych świątyń (1126) powstało w Polsce w okresie rządów gen. Jaruzelskiego, a nowe kościoły otwierano średnio co trzy dni. W miarę postępujących przemian społecznopolityczno-gospodarczych i swoistej stabilizacji tempo jednak stopniowo malało... Jeszcze jednak w 1986 roku budowano w Polsce jednocześnie ok. 900 nowych kościołów.

\section{AUTORSKI ZESPÓŁ SAKRALNY}

Autorami pierwszej koncepcji tego zespołu sakralnego, obejmującego kościół, plebanię, mieszkania sióstr i księży, byli Zofia i Zenon Łuczyńscy. Jednak po nagłej śmierci Z. Łuczyńskiego, w porozumieniu proboszczem parafii - ks. Stanisławem Podziornym, utworzono w 1985 roku nowy zespół z panią Zofią i moją osobą (Kurek J., 1998).

Zgodnie z przyjętymi już wcześniej ustaleniami, całość założenia miała mieć charakter i układ przestrzenny nawiązujący do dawnych założeń klasztornych o nieco rustykalnym charakterze - 0 stromych, łamanych „krakowskich” dachach. Uznaliśmy, że formy projektowanego zespołu, nie powinny rywalizować, z sąsiadującymi z nim, wielkoskalowymi 10 kondygnacyjnymi blokami mieszkalnymi. Jednocześnie priorytetem było spełnienie zaleceń liturgicznych II Soboru Watykańskiego.

W tamtym czasie w Nowej Hucie realizowano już kilka innych kościołów, jednak nie oznaczało to, że nowoprojektowany zespół sakralny uda się zrealizować już bez problemu. Na początek ko-

${ }^{5}$ Autorzy projektu „Architektura VII Dnia” doliczyli się w 2016 r. 3781 kościołów. 
nieczna była akceptacja komisji kurialnej, której konsultantem był wówczas prof. Witold Cęckiewicz. Komisja zażyczyła sobie przedstawienia dwóch wariantów koncepcji projektowych kościoła. W jednej bryła kościoła miała plan bardziej zwarty - centralny, a w drugiej rzut kościoła był bliższy krzyżowi łacińskiemu. Jednak obydwa warianty proponowały bryłę bezwieżową - jedynie z sygnaturką z prostym krzyżem, wieńczącą skrzyżowanie nawy i transeptu. Ostatecznie akceptację komisji zyskał wariant drugi - bliższy wzorcom tradycyjnym.

Kolejnym progiem do pokonania była konieczność uzyskania akceptacji miejskiej komisji urbanistyczno-architektonicznej (MKUA) przy Głównym Architekcie Krakowa. Wstępne uwagi Komisji nie dotyczyły architektury bryły kościoła, a jedynie domagano się ukazania powiązań komunikacji pieszej z tzw. Plantami Bieńczyckimi, nie będącymi własnością Parafii. Ostatecznie sformułowanie pozytywnej opinii o projekcie trwało ponad dwa lata... Realizacja postępowała już znacznie szybciej, a bryła kościoła praktycznie zrealizowana została bez wymaganego (i zatwierdzonego) architektonicznego projektu budowlanego - na podstawie jedynie projektu branżowego konstrukcji!

\section{PRÓBA OPISAMNIA STANU OBECNEGO}

Jak pisał 23 lata temu Tadeusz Gawłowski w krótkim eseju o jakości powojennej architektury obiektów sakralnych (Gawłowski J.T. 1998) krytycznie oceniał jakość architektury ostatnio wybudowanych kościołów - w okresie bezpośrednio przed pontyfikatem Jana Pawła II i po 1975 roku. Pomimo bowiem, że osiągnięto imponującą liczbę ok. 1500 nowo wybudowanych kościołów to: kościoły te nie reprezentują niestety oczekiwanej wysokiej jakości architektonicznej czy, ogólnie mówiąc artystycznej. Jedną z przyczyn tej zasmucającej sytuacji jest, jego zdaniem, zbyt mały udział w tych pracach przedstawicieli środowisk twórczych i naukowych, nie zawsze reprezentujących odpowiednie kwalifikacje profesjonalne i duchowe. Przywołuje on opinię ks. Janusza Pasierba, potępiającego sztukę kiepską, przeciętną i naśladowniczą, a postulującego realizowanie dzieł wybitnych nowych i twórczych (Gawłowski J.T. 1998 s.118).

Jak zauważa ks. Nadrowski: projektowanie i wykonywanie nowoczesnych kościołów nie jest skierowane w próżnię, czy ku fantazji zmieszanej z sentymentalizmem, ani też z czystym estetyzmem. (...) Zawsze poprzez treść i program danej budowli - odkrywamy i odczytujemy zarazem rzeczywistość religijną danego pokolenia oraz jego poczucie wartości. Dotyczy to oczywiście przede wszystkim osoby samego twórcy (Nadrowski H. 2000). Niewątpliwie wsparciem tej tezy są choćby realizacje - dzieła Stanisława Niemczyka, który dał się poznać jako wrażliwy twórca, głęboko przeżywający sacrum „swoich” kościołów (Kurek J. 2018 s.243). Niemczyk, niczego nie pozostawiał przypadkowi, wiele szkicował, uważał, że regułą działania powinno być myślenie! Odrzucał style, tzw. „języki form”, a inspirowany własną głęboką duchowością chrześcijańską, sięgał do korzeni przekazów wiary - tworząc formy niepowtarzalne, pozostające jednak w ścisłej relacji z wymogami liturgii i duchem Wiary... Jednocześnie jednak powtarzał, że rola architekta w społeczeństwie jest przede wszystkim usługowa!

Taka postawa i pokora w stosunku do podmiotu projektowego nie jest, jak się wydaje, typową dla większości „twórców”, którzy zwykle kreują formy w duchu auto-narcyzmu, mającego im samym zapewnić nieśmiertelność w pamięci odbiorców-wiernych.

\section{ANALIZY BADAWCZO-PROJEKTOWE I REALIZACYJNE}

Pragnąc uniknąć błędów wielu poprzedników, zespół projektowy ww. nowohuckiego zespołu sakralnego, poddał analizie przemiany i stan architektury sakralnej w Polsce XX wieku. Podstawowym celem było wówczas poznanie (analiza krytyczna) tendencji przejawiających się w projektowaniu kościołów - w tym realizowanej logiki proponowanych form, przy jednoczesnym respektowaniu zaleceń posoborowych. Jednocześnie starano się w maksymalnym stopniu uwzględnić w analizach i w pracach projektowych rozważania teoretyczne i praktyczne wnioski zawarte w dostępnej już wówczas pracy analitycznej s. Rosier-Siedleckiej (Rosier-Siedlecka 1979). Oczywiście nie dyskwalifikowało to dotychczasowych tysiącletnich doświadczeń w realizacji świątyń wczesno- 
chrześcijańskich czy średniowiecznych katedr. Równoprawna była tu także intuicyjna metoda badawczo-projektowa.

Ważnym elementem analiz projektowych była próba zdefiniowania wpływu otoczenia projektowanego obiektu na obiektywizowanie form nowego zespołu sakralnego i ich harmonijne zintegrowanie z zastaną architekturą średnich i wielkich bloków (4-10 kondygnacji). Dziś można by powiedzieć, że było to już wówczas swoiste projektowanie zrównoważone.

Ponad dwudziestoletnie funkcjonowanie zespołu sakralnego w Nowej Hucie pozwala dziś na dopełnienie wcześniejszych analiz o metody obserwacyjne - jako procesu ciągłego oraz o swoistą analizę metodą monograficzną - tu rozumianą jako obserwację funkcjonowania i poziomu akceptacji całości realizacji, w okresie korzystania z niej przez jedno (już!) pokolenie użytkowników.

\section{WNIOSKI - KONSTRUKTYWNY KONSERWATYZM?}

Ćwierć wieku które minęło od zrealizowania obiektu pozwala już dziś na ocenę trafności przyjętych założeń i rozwiązań projektowych. Uformowanie całości zespołu jako reminiscencję założeń klasztornych - tj. przeszczepienie średniowiecznych wzorców do współczesności - dało części budynków (sale katechetyczne, plebania, mieszkania księży i sióstr) niezbędną intymność i „wyciszenie”, za "otwarło” komunikacyjnie i funkcjonalnie powiązało z otaczającą przestrzenią bryłę kościoła. Swoistą strefę przejściową do zabudowy wysokiej stanowi zieleń plant bieńczyckich, sukcesywnie uzupełniana, w bezpośrednim sąsiedztwie kościoły, przez parafię. Ukośne linie łamanych (krakowskich) dachów kościoła i przylegających budynków są wystarczająco silnym akcentem-wyróżnikiem wśród otaczających prostopadłościennych form wielkopłytowych budynków mieszkalnych z lat 60 . XX wieku. Fenomen ten dostrzegł już $w$ dyskusji na MKUA jeden $z$ jej uczestników ${ }^{6}$ stwierdzając, że zespół ten wygląda jakby istniał już w tym miejscu przed powstaniem osiedla mieszkaniowego...

Przywodzi to na myśl pojęcie konstruktywny konserwatyzm (Kosiński W.1998) przyjęte przez śp. Wojciecha Kosińskiego, który przywołał wypowiedź Jana Pawła II, że: wierność korzeniom jest zawsze twórcza, gotowa do pójścia w głąb, otwarta na nowe wyzwania, wrażliwa na znaki czasu. Wyraża się ona także w trosce o rozwój rodzimej kultury. Wierność korzeniom oznacza nade wszystko umiejętność budowania organicznej więzi między odwiecznymi wartościami, które tyle razy sprawdziły się w historii, a wyznaniami (wyzwaniami? - przyp. JK) współczesnego świata.

Wydaje się, że ten właśnie racjonalny konstruktywny konserwatyzm pozwolił uchronić całość prezentowanego zespołu sakralnego przed przesadnym formalizmem - udziwnieniem i przesadą - co daje nadzieję, że wytrzyma on próbę czasu w znacznie dłuższym jeszcze okresie.

\section{BIBLIOGRAPHY}

Bystrzak T., Talowski, Wyd. Attyka, Kraków 2017, ISBN 978-83-6564-434-3

Gawłowski J. T., O projektowaniu i realizacji architektury obiektów sakralnych, /w:/ Udział pracowników Politechniki Krakowskiej w życiu Kościoła katolickiego za pontyfikatu Jan Pawła II, Kraków 1998, s.117-124.

POLSKIERADIO24 Oskar Sosnowski. Wielki architekt wspaniałych kościołów https://polskieradio24.pl/39/156/Artykul/2588354,Oskar-Sosnowski-Wielki-architekt-wspanialych-kosciolow dostęp/access 2021-11-28

Kosiński W., Konstruktywny konserwatyzm, /w:/ Udział pracowników Politechniki Krakowskiej w życiu Kościoła katolickiego za pontyfikatu Jan Pawła II, Kraków 1998, s. 179-186.

Kurek J., Kościół pw. Św. Józefa w Krakowie Nowej Hucie - dzieje jednego projektu, /w:/ Udział pracowników Politechniki Krakowskiej w życiu Kościoła katolickiego za pontyfikatu Jan Pawła II, Kraków 1998, s. 145148.

${ }^{6}$ Prof. Dariusz Kozłowski. 
Kurek J., Stanisław Niemczyk and his philosophy of architecture, /w:/ Space \& Form, 38_2018 s. 243.

Kurek J., Twórczość a potrzeby idealne - projekty Iwowskiego architekta Mariana Nikodemowicza, /w:/ Przestrzeń i Forma'17 (2012), s. 469-484.

Nadrowski H., Kościoły naszych czasów - dziedzictwo i perspektywy, Wydawnictwo WAM, Kraków 2000.

Rosier-Siedlecka M. E., Posoborowa architektura sakralna. Aktualne problemy projektowania architektury kościelnej, wyd. KUL, Lublin 1979.

Stefański K., Nowa forma w polskiej architekturze sakralnej początku XX wieku: Wojciechowski-SosnowskiWiwulski, Saeculum Christiana 10 (2003) nr 2.

Wroński J. S., Kościół św. Oblubieńca NMP, /w:/ Architektura nowohuckich kościołów 1967-2009, Wyd. Muzeum Historyczne Miasta Krakowa. Katalog wystawy 2010.

\section{AUTHOR'S NOTE}

For several decades, the author has been teaching construction, materials science and building physics at the faculties of architecture, Author is interested in historical and contemporary wooden and brick architecture. Hi also publishes analyzes and opinions on the quality of forms in contemporary architecture. He was the editor-in-chief of the nationwide ARCHIVOLTA quarterly and coeditor of the monthly Nasza Politechnika in Krakow. Chairman of the Wooden Architecture section of the Polish Academy of Sciences in Kraków.

\section{O AUTORZE}

Autor od kilkudziesięciu lat realizuje dydaktykę budownictwo, materiałoznawstwo i fizykę budowli na wydziałach architektury, zajmuje się także historyczną i współczesną architekturą drewnianą oraz murowaną. Publikuje także analizy i opinie nt. jakości form w architekturze współczesnej. Był redaktorem naczelnym ogólnopolskiego kwartalnika ARCHIVOLTA oraz współredaktorem miesięcznika Nasza Politechnika w Krakowie. Przewodniczący sekcji Architektury Drewnianej oddziału Polskiej Akademii Nauk w Krakowie.

Contact | Kontakt: pakurek@cyf-kr.edu.pl 